\title{
REDE CICLOVIÁRIA E ACIDENTES ENVOLVENDO CICLISTAS NA CIDADE DE LONDRINA/PR
}

\author{
Matheus Oliveira Martins da Silva \\ Mestrando no Programa de Pós-Graduação em Geografia \\ Universidade Estadual de Londrina, Departamento de Geociências \\ Laboratório de Análises Territoriais Campo Cidade - LATEC \\ Londrina, PR, Brasil \\ oliveiramartins.matheus@gmail.com \\ Fábio César Alves da Cunha \\ Professor Doutor \\ Universidade Estadual de Londrina, Departamento de Geociências \\ Laboratório de Análises Territoriais Campo Cidade - LATEC \\ Londrina, PR, Brasil \\ fabioalvescunha@gmail.com
}

\begin{abstract}
RESUMO
A presente pesquisa teve como objetivo analisar a realidade da rede cicloviária na cidade de Londrina com base no estudo do espaço urbano londrinense e no número de acidentes com bicicletas em um período de dez anos. Foram abordadas as legislações referentes à mobilidade urbana, partindo do Estatuto da Cidade e a Política Nacional de Mobilidade Urbana, que possibilitam uma discussão acerca do deslocamento por bicicletas baseado no Código de Trânsito Brasileiro e no Plano de Mobilidade por Bicicletas nas Cidades, nos quais são fornecidas as diretrizes para as Redes Cicloviárias. É exposto o projeto realizado na cidade de Londrina e as ações executadas até o ano de 2017, por meio de informações fornecidas pelo Instituto de Pesquisa e Planejamento Urbano de Londrina (IPPUL) e visitas in loco nas vias, trazendo à tona os principais problemas enfrentados pelos ciclistas. Dados do Corpo de Bombeiros do Paraná, por meio do Serviço Integrado de Atendimento ao Trauma (SIATE), possibilitaram mapear as 10 vias com mais acidentes envolvendo ciclistas, informações que fundamentaram a proposta de expansão e readequação da rede cicloviária existente com 24 ações, que são apresentadas no final do artigo.
\end{abstract}

Palavras-chave: Planejamento Urbano. Acidentes. Ciclovias. Ciclistas.

\section{CYCLING NETWORK AND ACCIDENTS INVOLVING CYCLISTS IN LONDRINA/PR CITY}

\begin{abstract}
The present research aims to analyze the reality of the cycling network in the city of Londrina based on the study of its urban space and the number of accidents with bicycles over a period of ten years. We discuss the legislation related to urban mobility in the City Statute, and the National Urban Mobility Policy, which enables discussing bicycling based on the Brazilian Traffic Code and the City Mobility Plan for Bicycles, both of which provide the guidelines for Cycle Track Networks. We address the city plan and the actions undertaken in Londrina up to 2017 through information provided by the Institute of Urban Planning and Research of Londrina (IPPUL), and on-site visits on the roads, bringing to light the main problems faced by cyclists. Data from the Paraná Fire Department through the Integrated Service of Trauma Assistance (SIATE) allowed mapping the ten tracks with more accidents involving cyclists. This information supported the aproach of expansion and readjustment of the existing cycling network with the 24 actions that are presented at the end of the paper.
\end{abstract}

Keywords: Urban planning. Accidents. Cycle paths. Cyclists.

\section{INTRODUÇÃO}

A precária mobilidade urbana, associada ao crescimento do tráfego e a violência no trânsito, constitui um dos principais problemas da cidade contemporânea. Nas duas primeiras décadas do século XXI, segundo o Departamento Nacional de Trânsito - Denatran somente na primeira década do século

\begin{tabular}{lllll}
\hline Caminhos de Geografia & Uberlândia & v. 21, n. 73 & Mar/2020 & p. 253-268 Página 253
\end{tabular}


XXI, a frota automotiva saltou de 29 milhões para 64 milhões de veículos (BRASIL, 2018a) e o número de mortes no trânsito de 28.995 para 40.989 no mesmo período (BRASIL, 2018b). Um crescimento que, historicamente, não é acompanhado pela infraestrutura viária nas cidades. Tal descompasso faz com que também ocorra um aumento expressivo do número de acidentes e mortes no trânsito.

Em 2001 foi criado o Estatuto da Cidade (Lei 10.257/2001), que passou a exigir de Municípios com mais de 500 mil habitantes a elaboração de planos de transporte, incorporando a política de mobilidade urbana como um dos instrumentos de desenvolvimento. No ano de 2012, foi aprovada a Política Nacional de Mobilidade Urbana (Lei 12.587/2012), que estabeleceu prazos para que também os municípios com mais de 20 mil habitantes pudessem elaborar seus planos de mobilidade.

Uma das diretrizes da Política Nacional de Mobilidade Urbana é a "Prioridade dos modos de transportes não motorizados sobre os motorizados" - aqui destaca-se sobretudo a bicicleta - e o desafio passa a ser como fornecer um mínimo de segurança para o cidadão que queira utilizar este modo de transporte, sobretudo nas médias e grandes cidades brasileiras.

Esse desafio passa não só por campanhas bem estruturadas de educação e conscientização no trânsito, mas também pela ampliação da infraestrutura urbana voltada para as bicicletas, na qual se destacam as ciclovias e ciclofaixas. Desta forma, a ampliação da infraestrutura da rede cicloviária nas cidades brasileiras passa a ser um caminho que contribui para dar maior segurança aos ciclistas e incentiva outros cidadãos a optar por este tipo de transporte, proporcionando, assim, ganhos substanciais para a mobilidade urbana.

A bicicleta também possui outras vantagens, como o preço acessível, pois, entre todos os veículos de transporte urbano, a bicicleta é o mais barato em termos de aquisição e manutenção, eficiência energética, baixa perturbação ambiental, contribuição à saúde, flexibilidade - pois não está presa a horários nem rotas preestabelecidas -, menor necessidade de espaço público para movimentação e, por fim, rapidez. Há estudos que constatam ser a bicicleta o meio de transporte mais rápido em deslocamentos nas áreas urbanas mais densas das cidades (BRASIL, 2001b).

Apesar dessas vantagens e da exigência, por parte da Política Nacional de Mobilidade Urbana, de investimentos no transporte cicloviário, se constata que na cidade de Londrina/PR este modal de transporte vem recebendo ainda pouca atenção, fato este que se reflete no número de acidentes envolvendo ciclistas e que juntos constituíram a problemática fundamental da presente investigação.

Com base nessa realidade, a pesquisa teve como principal objetivo analisar a atual situação da rede cicloviária na cidade de Londrina/PR, a segunda maior cidade do Estado do Paraná. Localizada no norte deste Estado, contava em 2017 com aproximadamente 560 mil habitantes e é polo de um aglomerado metropolitano que já superou um milhão de habitantes (CUNHA, 2014). Um outro objetivo foi fazer o levantamento do número de acidentes com bicicletas num período de uma década e, com isso, identificar as vias mais perigosas para o ciclista nessa cidade. Com base nos levantamentos foi possível elaborar uma proposta de expansão e readequação da rede cicloviária, com 24 ações pontuais, que visam atingir todas as regiões da cidade, dar maior conexão à rede cicloviária e maior segurança para os cidadãos envolvidos com este tipo de transporte.

\section{PROCEDIMENTOS METODOLÓGICOS}

Constituíram etapas da metodologia de pesquisa uma pesquisa bibliográfica sobre o transporte por bicicletas e mobilidade urbana e uma pesquisa documental por meio da Legislação vigente, do Manual de Planejamento Cicloviário do Ministério dos Transportes e do Plano de Mobilidade por Bicicleta nas Cidades, para caracterizar a realidade e as propostas relacionadas à mobilidade por bicicleta. Além disso, foram utilizados os projetos do Instituto de Pesquisa e Planejamento Urbano de Londrina (IPPUL) para obter informações sobre o processo de construção da Rede Cicloviária de Londrina e sua atual situação com visitas a campo.

Para entender a vulnerabilidade dos ciclistas na cidade de Londrina/PR, foi construído um banco de dados por meio do software ArcGis 10.2.1 com os dados de acidentes a partir de informações obtidas no site do Corpo de Bombeiros, por meio do Serviço Integrado de Atendimento ao Trauma em Emergência (SIATE) e o Sistema de Registro e Estatística de Ocorrências do Corpo de Bombeiros do Paraná, que é responsável pelo resgate, registro da ocorrência e disponibilização dos dados virtualmente. O banco de dados foi construído a partir do 3ํGupamento, que integra o município de Londrina, partindo do dia 1 de janeiro de 2006 (ano da primeira versão da Rede Cicloviária de

$\begin{array}{llllll}\text { Caminhos de Geografia } & \text { Uberlândia } & \text { v. 21, n. 73 } & \text { Mar/2020 } & \text { p. 253-268 } & \text { Página } 254\end{array}$


Londrina) até o dia 31 de dezembro de 2016, totalizando uma análise de onze anos. Com esta análise foi possível espacializar as vias com maiores números de acidentes nos seguintes tipos de ocorrências: acidentes entre bicicletas, acidentes envolvendo ônibus e bicicletas, acidentes envolvendo caminhões e bicicletas, acidentes envolvendo motos e bicicletas e acidentes envolvendo carros e bicicletas e por fim definir ações emergenciais e expansão e readequação da rede cicloviária de Londrina com base em parâmetros do Plano de Mobilidade por Bicicleta nas Cidades (BRASIL, 2007).

\title{
RESULTADOS E DISCUSSÃO
}

\section{a bicicleta no Código de Trânsito Brasileiro e no Plano de Mobilidade no Brasil}

O Código de Trânsito Brasileiro (CTB) instituído pela Lei № 9.503, de 23 de dezembro de 1997, em seu artigo 96 define que a bicicleta é um veículo e como deve ser seu trânsito:

\begin{abstract}
Nas vias urbanas e nas rurais de pista dupla, a circulação de bicicletas deverá ocorrer, quando não houver ciclovia, ciclofaixa, ou acostamento, ou quando não for possível a utilização destes, nos bordos da pista de rolamento, no mesmo sentido de circulação regulamentado para a via, com preferência sobre os veículos automotores (BRASIL, 1997).
\end{abstract}

O CTB mostra também, no Artigo 255, que "é dever do ciclista seguir certas regras, como não conduzir a bicicleta em passeios (calçada) onde não seja permitida a circulação desta", mas também traz à tona que estacionar ou transitar sobre ciclovias ou ciclofaixas é crime:

Art. 181: Estacionar o veículo [...] VIII - no passeio ou sobre faixa destinada a pedestre, sobre ciclovia ou ciclofaixa [...] infração: grave; penalidade: multa; medida administrativa: remoção do veículo; Art. 193: Transitar com o veículo em calçadas, passeios, passarelas, ciclovias, ciclofaixas [...] infração: gravíssima; penalidade: multa. (BRASIL, 1997).

A partir da bicicleta é possível resgatar toda a discussão sobre o direito à cidade, (re)estabelecendo a cidadania, tendo em vista que historicamente a bicicleta acabou se popularizando nos anos 1950 do século passado; caso seja estimulado o seu uso, pode se tornar uma escolha de vida. Para isso, é necessário compreender como o Estado atua na (re)formulação de políticas de incentivo ao uso deste veículo.

Em 1999, com os dados levantados pelo antigo Grupo de Estudos para a Integração da Política de Transportes (GEIPOT), unificados nos documentos "Planejamento Cicloviário - Diagnóstico Nacional" e "Manual de Planejamento Cicloviário", possibilitaram a construção de informações completas do setor cicloviário. No entanto, segundo o Ministério das Cidades (BRASIL, 2007, p. 25), "a extinção desse órgão federal, em 2001, mesmo ano de publicação dos documentos, impossibilitou que estes fossem distribuídos aos municípios",. O primeiro volume trouxe informações sobre o uso e a infraestrutura; com isso foi montada uma classificação dos municípios com melhores condições para as bicicletas. O segundo volume apresentou as normas, regras e exemplos de técnicas para a construção de infraestrutura em áreas urbanas (BRASIL, 2007). Em 2004, o Governo Federal lançou o Programa Brasileiro de Mobilidade por Bicicleta, o chamado "Bicicleta Brasil", fazendo com que o País pela primeira vez passasse a ter um programa específico para a bicicleta.

No ano de 2007, o Ministério das Cidades, no processo de implementação da Política de Mobilidade Urbana para a Construção de Cidades Sustentáveis, reforça a preocupação com a inclusão social, a sustentabilidade ambiental e, consequentemente, a gestão participativa e a equidade no uso do espaço público. Segundo o Ministério das Cidades (BRASIL, 2007, p.7), a criação do "Caderno de Referência para elaboração de Plano de Mobilidade por Bicicleta nas Cidades" representa um esforço da Secretaria Nacional de Transporte e da Mobilidade Urbana (SeMob) em fornecer subsídios para os municípios que temham intenção de implantar um plano cicloviário integrado aos demais modos existentes, formando uma rede de transporte. Serve também como uma evolução e atualização dos conceitos existentes e defendidos pelo Governo Federal, dando uma nova dimensão ao uso da bicicleta como meio de transporte integrado às redes de mobilidade, cujo planejamento deve considerar os aspectos locais e regionais, por meio da participação ativa da sociedade, inclusive as organizações de usuários de bicicletas.

A SeMob verificou o uso crescente da bicicleta como meio de transporte, além do lazer, mas também por motivo de trabalho e estudo, considerando que deve ser dado um tratamento adequado para o

$\begin{array}{llllll}\text { Caminhos de Geografia } & \text { Uberlândia } & \text { v. 21, n. 73 } & \text { Mar/2020 } & \text { p. 253-268 } & \text { Página } 255\end{array}$


transporte que tem suma importância nos deslocamentos urbanos de milhares de pessoas. Para o Ministério das Cidades (BRASIL, 2007), "isto exige políticas públicas específicas que devem ser implementadas pelas três esferas de governo". As diretrizes da Política Nacional da Mobilidade Urbana foram discutidas no processo da Conferência das Cidades, previsto pelo Estatuto da Cidade, por meio da participação popular nas discussões sobre a cidade, quando a SeMob realizou um fórum para discussão do Programa Brasileiro de Mobilidade por Bicicleta - Bicicleta Brasil, lançado em setembro de 2004, em que foi discutida uma política específica para o transporte cicloviário no País.

A inclusão da bicicleta nos deslocamentos urbanos deve ser considerada elemento fundamental para a implantação do conceito de Mobilidade Urbana para construção de cidades sustentáveis, como forma de redução do custo da mobilidade das pessoas e da degradação do meio ambiente. Sua integração aos modos coletivos de transporte é possível, principalmente com os sistemas de alta capacidade, o que já tem ocorrido, mesmo que espontaneamente, em muitas grandes cidades (BRASIL, 2007, p. 7).

Dentro deste contexto, é evidente que a inserção da bicicleta nos deslocamentos urbanos dentro dos Planos de Transporte e Mobilidade Urbana proporciona uma inclusão social, além de contribuir para a melhoria da saúde da população e da própria cidade, que passa a apresentar uma grande redução na emissão de agentes poluentes causados pelos veículos motorizados.

Com isso, a integração da bicicleta nos atuais sistemas de circulação deve ser considerada, segundo o Ministério das Cidades (BRASIL, 2007, p. 13), "como elemento integrante de um novo desenho urbano, que contemple a implantação de infraestruturas, bem como novas reflexões sobre o uso e a ocupação do solo urbano".

A valorização do automóvel como meio de transporte "ideal", reflete-se na infraestrutura favorável a este meio, causando uma desumanização dos espaços urbanos onde cada vez menos os pedestres e ciclistas possuem local adequado para deslocamento. Segundo o Ministério das Cidades (BRASIL, 2007, p. 100), devem ser criados espaços públicos de encontro e convívio das pessoas, com acessos para pedestres e ciclistas, proporcionando lugares mais saudáveis, menos barulhentos, menos poluídos. Para os ciclistas, esses acessos são dados por meio das ciclovias e ciclofaixas. As ciclovias (Figura 1) são definidas pelo Caderno de Referência para elaboração de Plano de Mobilidade por Bicicleta nas Cidades como:

[...] o espaço destinado à circulação exclusiva de bicicletas, separado da pista de rolamento dos outros modos por terrapleno, com mínimo de 0,20 m de desnível, sendo, habitualmente, mais elevada do que a pista de veículos motorizados. No sistema viário, pode localizar-se ao longo do canteiro central ou nas calçadas laterais. A ciclovia também pode assumir traçado totalmente independente da malha viária urbana ou rodoviária (como as ciclovias situadas sobre antigos leitos ferroviários). Nesses casos, deverá ter controle de acesso, ou seja, a acessibilidade dos ciclistas a ela deverá ser projetada de forma segura e eficiente em todos seus cruzamentos com outras estruturas viárias. (BRASIL, 2007, p.101).

Figura 1 - Exemplo de Ciclovia.

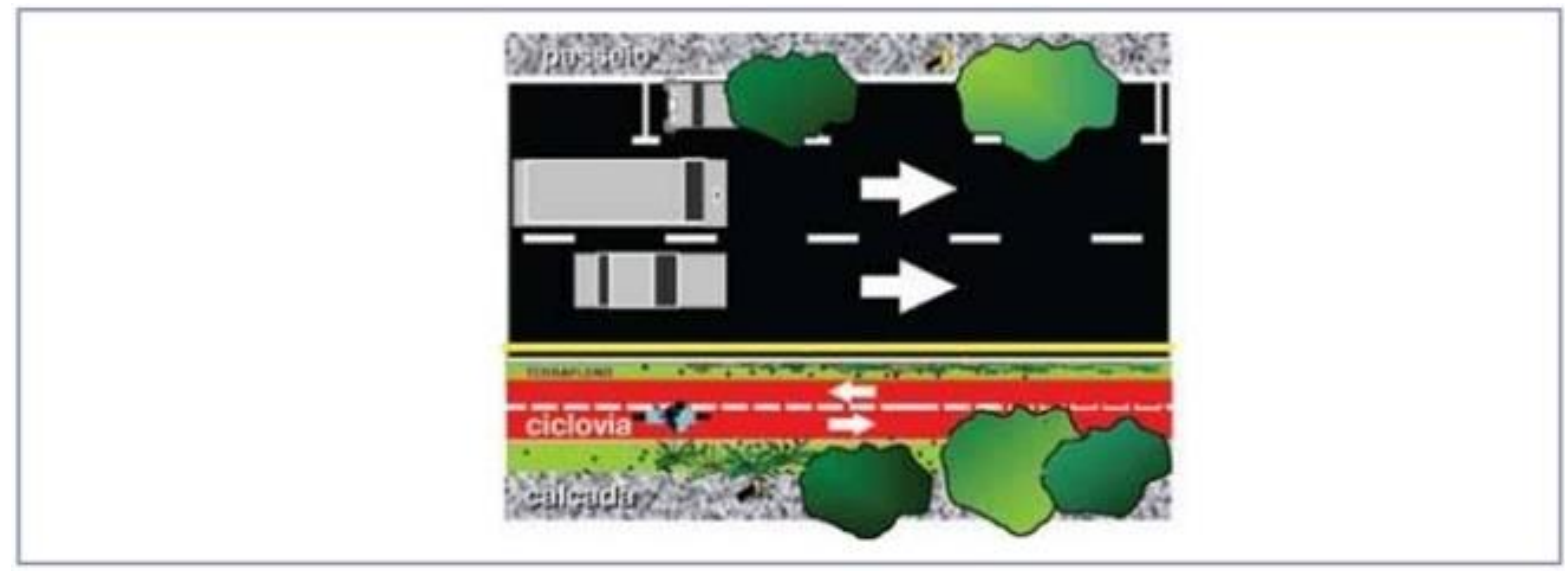

Fonte - BRASIL (2001b).

\begin{tabular}{llllll}
\hline Caminhos de Geografia & Uberlândia & v. 21, n. 73 & Mar/2020 & p. 253-268 & Página 256
\end{tabular}


Segundo o Ministério das Cidades, também pode ser considerada ciclovia a faixa destinada à circulação de bicicletas situada na pista utilizada pelo tráfego motorizado, desde que haja segregação absoluta dela, proporcionada por elementos de concreto. A ciclovia pode ser unidirecional, que não é comumente adotada no Brasil. Ela é utilizada em países com larga tradição no uso da bicicleta, como Holanda, Alemanha e Dinamarca. A sua utilização é facilitada quando se tem uma rede cicloviária completa, em que a bicicleta é compreendida como um modal igualitário aos demais veículos na via pública. A ciclovia também pode ser bidirecional, que é muito usual no Brasil, variando sua adoção de acordo com o porte das cidades, geralmente utilizada nos grandes centros urbanos como espaço de lazer e, no interior do país, como ciclovia funcional (BRASIL, 2007).

Já as ciclofaixas (Figura 2) são definidas pelo Ministério das Cidades (BRASIL, 2007, p.103) como "o espaço destinado à circulação de bicicletas, contíguo à pista de rolamento de veículos automotores, sendo dela separada por pintura e/ou dispositivos delimitadores denominados de tachas pelo CTB".

Figura 2 - Exemplo de Ciclofaixa.

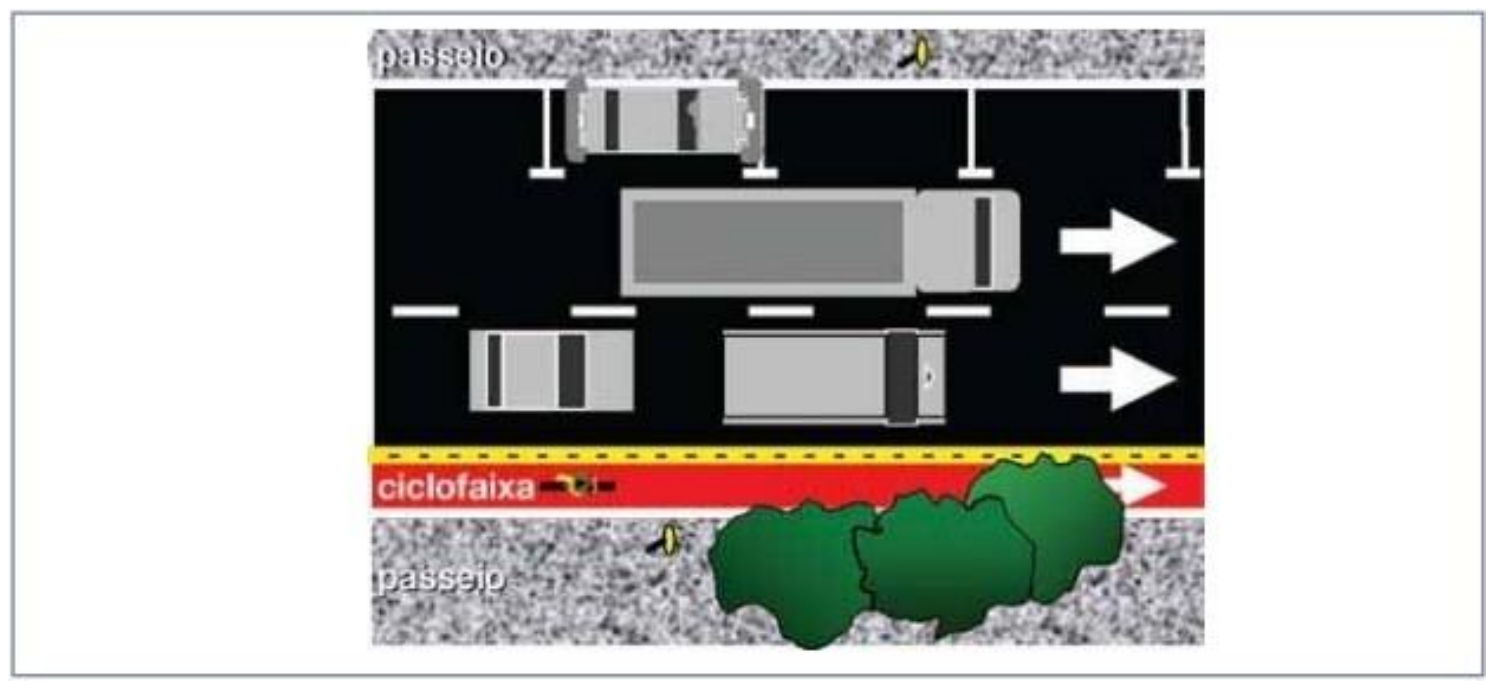

Fonte - BRASIL (2001b).

A ciclofaixa deve ser sempre unidirecional, com o objetivo de garantir segurança elevada em toda sua extensão. É conveniente que ela seja canalizada na aproximação dos cruzamentos. Com isso, ela deixa a condição de ciclofaixa para ser uma ciclovia, em uma pequena extensão. Em relação à rota, quanto estiver localizada em vias de sentido único de circulação, deve ser prevista rota que faça a mesma ligação em sentido contrário, proporcionando um percurso de ida e volta (BRASIL, 2007).

O Caderno recomenda, entre os tratamentos indicados para a implantação de um sistema cicloviário, a instalação de semáforos específicos para os ciclistas associados à linha de retenção avançada, paraciclos ou bicicletários e ressalta a adoção de arborização ao longo das vias para dar sombra e conforto aos ciclistas durante o percurso.

As características dos projetos cicloviários podem ter forte variação na geometria e sinalização, dependendo da característica das redes na qual estão inseridas e levando em consideração os principais tipos de usos.

\section{REDE CICLOVIÁRIA DE LONDRINA}

Segundo informações do IPPUL, apesar de Londrina contar com algumas ciclovias e ciclofaixas construídas, sobretudo, a partir de 2004 e direcionadas para o lazer, a sua expansão, de forma mais eficaz, ocorreu só após a promulgação daLei Federal 12.587/2012, que exige que o transporte público seja integrado a outras formas de mobilidade urbana não motorizadas - como pedestres e ciclistas. Segundo o Ministério das Cidades (BRASIL, 2007, p.43), a implantação de infraestrutura

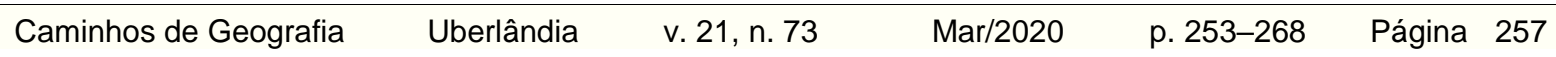


cicloviária deve garantir segurança a ciclistas e demais usuários das vias, promovendo visibilidade e previsibilidade, sendo pensada levando em consideração a relação entre tráfego e velocidade.

Com base no Plano Nacional de Mobilidade Urbana Sustentável, os órgãos públicos devem promover ações atendendo os seguintes princípios:

\begin{abstract}
A estruturação de sistemas cicloviários nas cidades brasileiras garantirá uma alternativa de deslocamento à população, principalmente ao cidadão de baixa renda, democratizando o transporte de forma socialmente inclusiva e ecologicamente sustentável. Buscando cumprir uma das diretrizes básicas estabelecidas na Política Nacional de Mobilidade Urbana Sustentável, os poderes públicos municipais devem promover políticas e ações que visem atender os seguintes princípios: 1 . Estimular o uso de bicicletas como modo alternativo de transportes, priorizando sua integração à rede de transporte público; 2. Assegurar mobilidade e acessibilidade aos usuários de bicicletas; 3 . Minimizar riscos de acidentes e interferências decorrentes do tráfego de veículos, mobiliário, vegetação, sinalização e publicidade; 4. Facilitar destinos, concebendo rotas contínuas e integradas entre habitações, comércio, serviços, espaços públicos, equipamentos e lazer; 5. Aproveitar o espaço urbano, diversificando seus benefícios; e 6. Observar os aspectos estéticos e harmônicos do traçado e seu entorno (calçadas, praças, parques) (KRAFT, 1975 apud DUTRA, 2007, p.2).
\end{abstract}

Com base nesses princípios, no ano de 2006, o IPPUL realizou 1000 entrevistas com a população para analisar o uso da bicicleta como meio de transporte na cidade. A entrevista foi dividida da seguinte forma: 500 usuários da bicicleta como meio de transporte no dia a dia e 500 pessoas que se utilizam de outras formas de locomoção - transporte público, veículo particular ou a pé, com questões como deslocamento diário, ponto de origem e destino e quais as dificuldades enfrentadas no trajeto. Com esses dados, planejou-se $60 \mathrm{~km}$ de ciclovias para a cidade.

Dos primeiros estudos realizados em 2006 até agora, pouca coisa foi executada com relação a esse planejamento. O projeto inicial sofreu diversas alterações nesse período e até o ano de 2012 a cidade contava com apenas $12 \mathrm{~km}$ de ciclovias, sendo que cerca de 1,8 km ficava no entorno do Lago Igapó e seu uso é projetado ao lazer. Novas pesquisas foram realizadas pelo IPPUL em 2013 para compreender o perfil do ciclista londrinense e o motivo de deslocamento (Quadro 1).

Quadro 1 - Motivo de deslocamento dos ciclistas de Londrina: Pesquisa IPPUL, 2013.

\begin{tabular}{|c|c|c|}
\hline Motivo de viagem & Entrevistados & Porcentagem \\
\hline Estudo & 389 & $24 \%$ \\
\hline Lazer & 650 & $41 \%$ \\
\hline Trabalho & 561 & $35 \%$ \\
\hline Total & 1600 & $100 \%$ \\
\hline \multicolumn{2}{|c}{} \\
\hline
\end{tabular}

Pode-se observar que há um predomínio do deslocamento por bicicleta para prática do lazer (41\%). Porém, levando-se em conta os motivos trabalho e estudo, estes atingem $59 \%$ dos entrevistados, o que mostra que os ciclistas de Londrina utilizam a bicicleta muito mais para trabalho e estudo do que para o lazer.

A partir da coleta desses dados, a Diretoria de Trânsito e Sistema Viário do IPPUL planejou 318,8 km de vias para bicicletas na cidade de Londrina (Figura 3), cerca de 5 vezes mais do que foi planejado anteriormente, contando com bicicletários em pontos estratégicos de destino da maioria dos usuários, como o centro comercial da cidade, visando promover a integração com o transporte coletivo para viabilizar o cumprimento de longas distâncias, como sugerido pelos entrevistados.

$\begin{array}{lllll}\text { Caminhos de Geografia } & \text { Uberlândia } & \text { v. 21, n. } 73 & \text { Mar/2020 } & \text { p. 253-268 Página } 258\end{array}$


Figura 3 - Proposta da Rede Cicloviária com mais de 300 km para a Cidade de Londrina/PR.

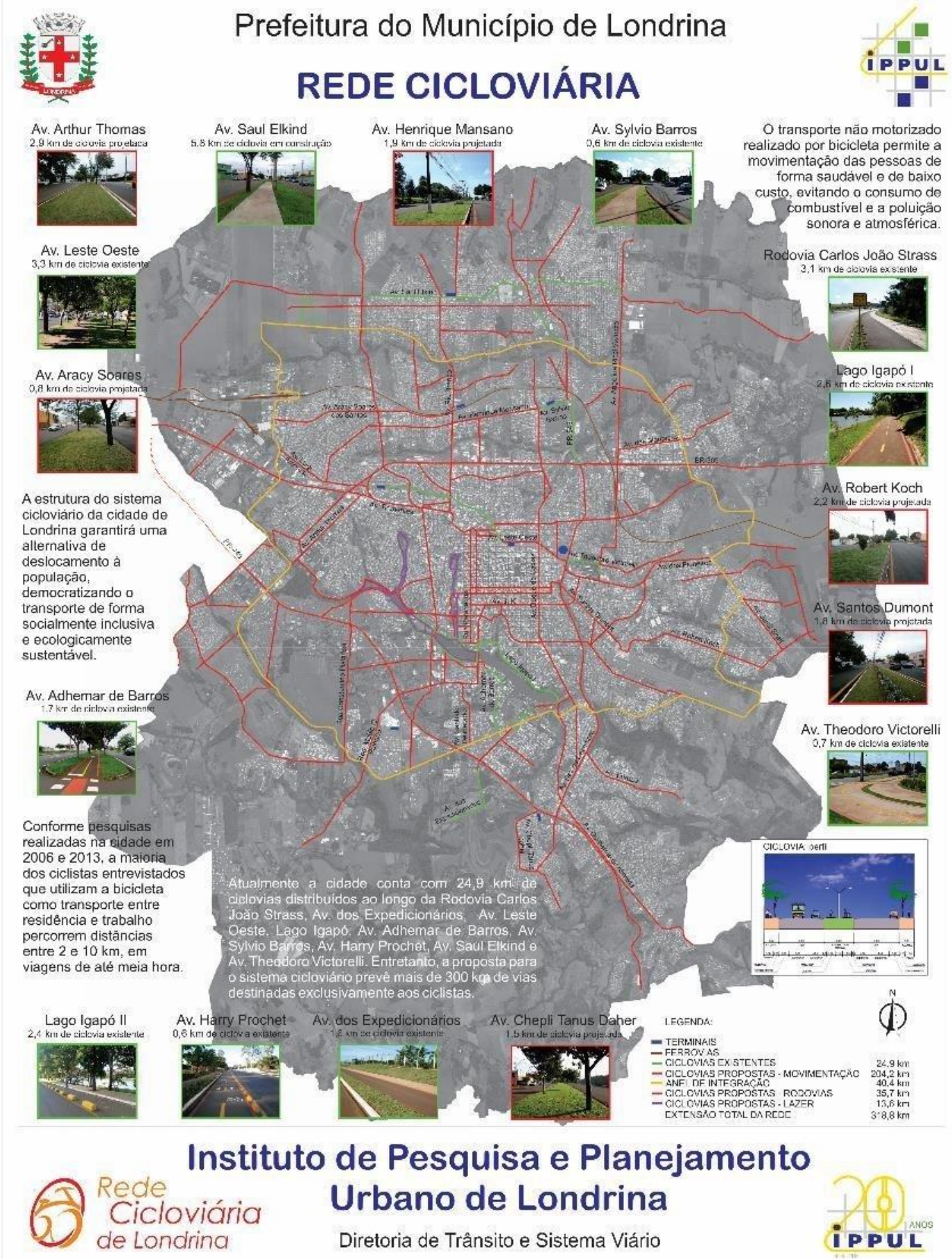

Fonte - IPPUL (2013).

O mapa encontra-se desatualizado e, segundo o IPPUL, no ano de 2017, a cidade contava com 38 $\mathrm{km}$ de ciclovias. Algumas vias já existiam antes de 2009 (Avenida Leste Oeste, Avenida das Maritacas, Rodovia João Carlos Strass e Avenida Expedicionários), mas faziam parte de projetos que ainda não abrangiam o Plano Cicloviário da cidade. A rede cicloviária de Londrina se apresenta desconexa, pouco extensa e com predominância no centro sul, nas proximidades do Lago Igapó, principal local de lazer da cidade. Com base em todo esse levantamento documental e in loco, 
através de averiguações a campo, foi possível espacializar a rede cicloviária londrinense (Figura 4 e Quadro 2).

Figura 4 - Rede Cicloviária de Londrina em 2017.

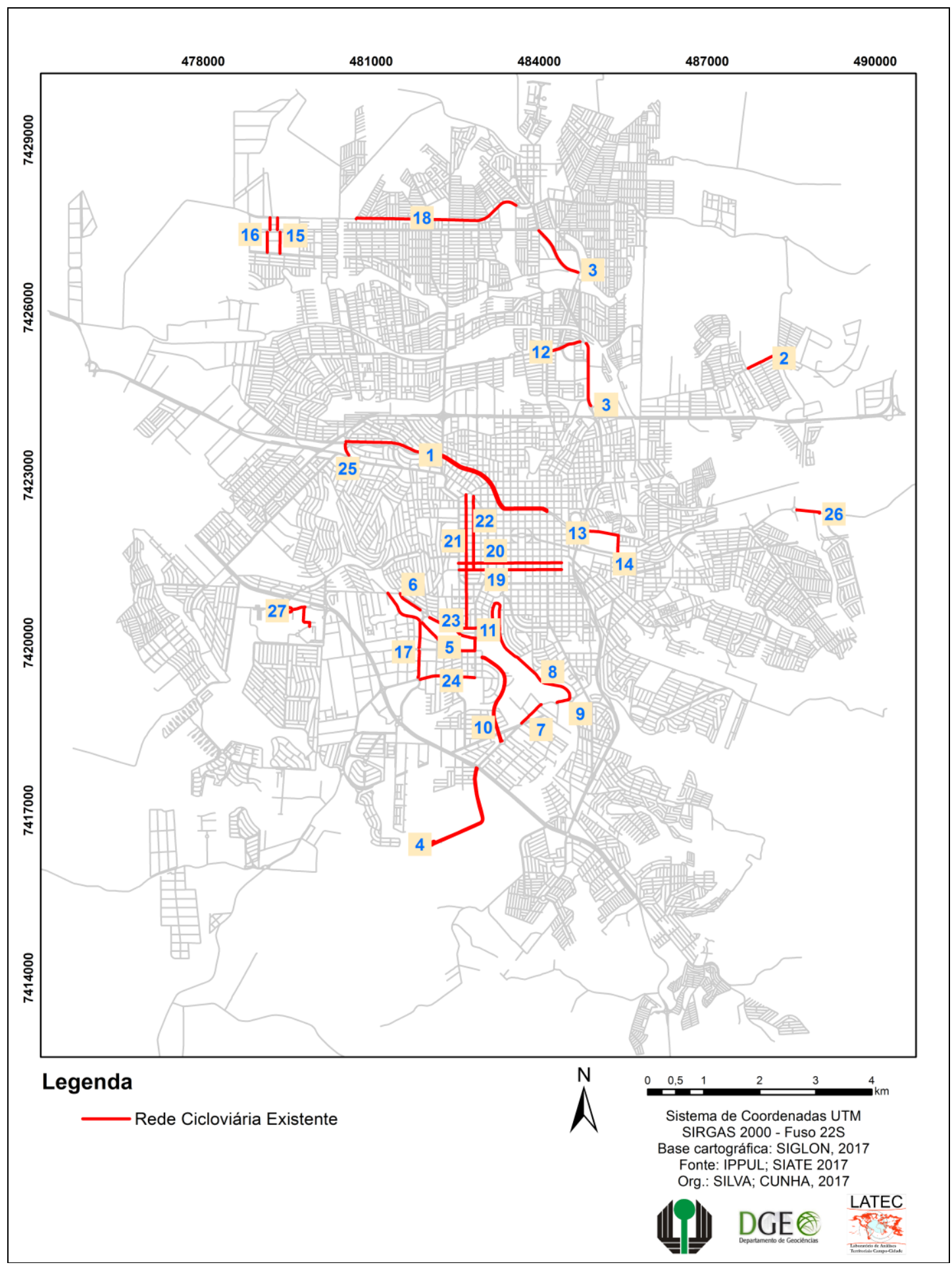

Fonte - IPPUL (2017) Org.: Os autores (2017).

Para o IPPUL, apesar de a rede cicloviária atingir apenas $10 \%$ do projeto de 2013 , a meta é aumentar a malha cicloviária com o Novo Plano de Mobilidade Urbana do município, que buscará integrar o ciclista ao transporte público, ficando mais fácil para o ciclista cumprir percursos de longa distância.

\begin{tabular}{llllll}
\hline Caminhos de Geografia & Uberlândia & v. 21, n. 73 & Mar/2020 & p. 253-268 & Página 260
\end{tabular}


Quadro 2 - Síntese da Rede Cicloviária de Londrina em 2017.

\begin{tabular}{|c|c|c|c|c|c|c|}
\hline & Localização & Tipo & Disposição & $\begin{array}{c}\text { Extensão } \\
(\mathbf{m})\end{array}$ & Implantação & Projeto \\
\hline 1 & $\begin{array}{l}\text { Av. Leste Oeste } \\
\text { (Trecho Oeste) }\end{array}$ & Ciclovia & $\begin{array}{c}\text { Canteiro } \\
\text { segregada }\end{array}$ & 3.275 & 1988 & $\mathrm{SMOP}^{1}$ \\
\hline 2 & Av. das Maritacas & Ciclofaixa & $\begin{array}{c}\text { Pista } \\
\text { sinalizada }\end{array}$ & 600 & 2004 & IPPUL \\
\hline 3 & $\begin{array}{l}\text { Rodovia Carlos } \\
\text { João Strass }\end{array}$ & Ciclovia & $\begin{array}{c}\text { Calccada } \\
\text { segregada }\end{array}$ & 2.622 & 2006 & DER-PR ${ }^{2}$ \\
\hline 4 & $\begin{array}{c}\text { Av. } \\
\text { Expedicionários }\end{array}$ & Ciclovia & $\begin{array}{l}\text { Calccada } \\
\text { segregada }\end{array}$ & 1.576 & 2006 & DER-PR \\
\hline 5 & Lago Igapó II & Ciclovia & $\begin{array}{c}\text { Pista } \\
\text { segregada }\end{array}$ & 2.396 & 2009 & IPPUL \\
\hline 6 & $\begin{array}{c}\text { Aterro Lago lgapó } \\
\text { II }\end{array}$ & Ciclovia & $\begin{array}{c}\text { Pista } \\
\text { segregada }\end{array}$ & 1.420 & 2010 & IPPUL \\
\hline 7 & AV. Harry Prochet & Ciclovia & $\begin{array}{c}\text { Pista } \\
\text { segregada }\end{array}$ & 569 & 2011 & IPPUL \\
\hline 8 & $\begin{array}{c}\text { Lago lgapó I } \\
\text { (parque) }\end{array}$ & Ciclovia & $\begin{array}{l}\text { Pista } \\
\text { segregada }\end{array}$ & 1.786 & 2012 & IPPUL \\
\hline 9 & $\begin{array}{l}\text { Rua Almeida } \\
\text { Garrett }\end{array}$ & Ciclovia & $\begin{array}{l}\text { Calcada } \\
\text { segregada }\end{array}$ & 142 & 2012 & IPPUL \\
\hline 10 & $\begin{array}{c}\text { Av. Adhemar } \\
\text { Pereira de Barros }\end{array}$ & Ciclovia & $\begin{array}{c}\text { Canteiro } \\
\text { segregada }\end{array}$ & 1.706 & 2012 & IPPUL \\
\hline 11 & $\begin{array}{c}\text { Rua Aminthas de } \\
\text { Barros }\end{array}$ & Ciclovia & $\begin{array}{c}\text { Calcada } \\
\text { compartilhada }\end{array}$ & 458 & 2012 & IPPUL \\
\hline 12 & Av. Sylvio Barros & Ciclovia & $\begin{array}{c}\text { Canteiro } \\
\text { segregada }\end{array}$ & 670 & 2013 & IPPUL/EIV \\
\hline 13 & $\begin{array}{l}\text { Av. Theodoro } \\
\text { Victorelli }\end{array}$ & Ciclovia & $\begin{array}{l}\text { Calcada } \\
\text { segregada }\end{array}$ & 700 & 2013 & IPPUL/EIV \\
\hline 14 & $\begin{array}{c}\text { Rua Santa } \\
\text { Terezinha } \\
\end{array}$ & Ciclovia & $\begin{array}{c}\text { Calçada } \\
\text { segregada }\end{array}$ & 200 & 2013 & IPPUL/EIV \\
\hline 15 & $\begin{array}{l}\text { R. Yoneko Shime } \\
\text { - R. Luiz Leoni }\end{array}$ & Ciclovia & $\begin{array}{c}\text { Calccada } \\
\text { segregada }\end{array}$ & 687 & 2014 & IPPUL/Loteador \\
\hline 16 & $\begin{array}{l}\text { R. Mitsuki Shime - } \\
\text { R. Benedito } \\
\text { Souza }\end{array}$ & Ciclovia & $\begin{array}{l}\text { Calccada } \\
\text { segregada }\end{array}$ & 671 & 2014 & IPPUL/Loteador \\
\hline 17 & $\begin{array}{c}\text { Av. Ayrton Senna } \\
\text { da Silva }\end{array}$ & Ciclofaixa & $\begin{array}{c}\text { Pista } \\
\text { sinalizada }\end{array}$ & 1.025 & 2015 & IPPUL/EIV \\
\hline 18 & $\begin{array}{l}\text { Av. Saul Elkind } \\
\text { (Oeste) }\end{array}$ & Ciclovia & $\begin{array}{l}\text { Canteiro } \\
\text { segregada }\end{array}$ & 3.000 & $2015 / 2016$ & IPPUL \\
\hline 19 & Rua Alagoas & Ciclofaixa & $\begin{array}{c}\text { Pista } \\
\text { sinalizada }\end{array}$ & 1.700 & $2015 / 2016$ & IPPUL \\
\hline 20 & $\begin{array}{l}\text { Rua Espírito } \\
\text { Santo }\end{array}$ & Ciclofaixa & $\begin{array}{c}\text { Pista } \\
\text { sinalizada }\end{array}$ & 1.700 & $2015 / 2016$ & IPPUL \\
\hline 21 & Rua Paranaguá & Ciclofaixa & $\begin{array}{c}\text { Pista } \\
\text { sinalizada }\end{array}$ & 1.340 & $2015 / 2016$ & IPPUL \\
\hline 22 & Rua Santos & Ciclofaixa & $\begin{array}{c}\text { Pista } \\
\text { sinalizada }\end{array}$ & 1.320 & $2015 / 2016$ & IPPUL \\
\hline 23 & $\begin{array}{c}\text { Rua Aminthas de } \\
\text { Barros }\end{array}$ & Ciclofaixa & $\begin{array}{c}\text { Pista } \\
\text { sinalizada }\end{array}$ & 350 & $2015 / 2016$ & IPPUL \\
\hline 24 & $\begin{array}{l}\text { Av. Madre Leônia } \\
\text { Milito }\end{array}$ & Ciclovia & $\begin{array}{c}\text { Canteiro } \\
\text { segregada }\end{array}$ & 1.000 & 2016 & IPPUL/EIV \\
\hline 25 & Av. Universo & Ciclovia & $\begin{array}{l}\text { Canteiro } \\
\text { segregada }\end{array}$ & 180 & 2017 & IPPUL/EIV \\
\hline 26 & Boulevard MRV & Ciclovia & $\begin{array}{c}\text { Calccada } \\
\text { segregada }\end{array}$ & 340 & 2017 & IPPUL/Loteador \\
\hline 27 & UEL & Ciclofaixa & $\begin{array}{c}\text { Pista } \\
\text { sinalizada }\end{array}$ & - & 2017 & UEL $^{3}$ \\
\hline
\end{tabular}

Fonte - IPPUL (2017). Org.: Os autores (2017).

Sequndo o Instituto, a primeira etapa da pesquisa de 2013 indicou que, embora os locais de moradia dos entrevistados esteiam distribuídos nas diversas reqiões da cidade, é possível perceber que o destino, principalmente de trabalho, destes ciclistas está concentrado na área central da cidade. Com isso, fica nítido que o trabalhador não é favorecido com a atual realidade da rede cicloviária; por outro lado, a rede cicloviária favorece os moradores que se concentram nas regiões centro-sul, em áreas

1 Secretaria Municiapal de Obras e Pavimentação de Londrina

2 Departamento de Estradas de Rodagem do Paraná

${ }^{3}$ A ciclofaixa da Universidade Estadual de Londrina (UEL) não consta na contagem do projeto oficial do IPPUL.
Caminhos de Geografia
Uberlândia
v. 21, n. 73
Mar/2020
p. 253-268
Página 261 
mais privileaiadas por este tipo de infraestrutura e que se utilizam desse meio de locomoção, na maioria das vezes, apenas para o lazer.

Além dos investimentos oriundos de recursos públicos das esferas Federal e Estadual, algumas das vias implantadas contaram com recursos advindos de medidas mitigatórias propostas pelo Estudo de Impacto de Vizinhança (EIV), um instrumento que tem sua origem no Estatuto da Cidade e visa viabilizar condições alternativas para compensar impactos de empreendimentos nas cidades. Segundo Paulino (2011):

Os desdobramentos socioterritoriais da atividade que se quer implantar devem ser enquadrados no que o legislador define como medidas, até para que o empreendedor assuma previamente as responsabilidades inerentes, mediante assinatura de Termo de Ajuste de Conduta prévio à concessão de licença de operação do empreendimento. Basicamente, as medidas devem ser: a) compatibilizadoras, as quais devem indicar como o empreendimento se compatibiliza com a vizinhança, notadamente nos aspectos referentes aos serviços públicos e bens comunitários, aos fluxos, à infra-estrutura (sic), à paisagem urbana, em suma, à dinâmica socioterritorial do lugar pretendido; mitigatórias, que deverão apontar como os impactos que admitem controle serão tratados com vistas à prevencão de incômodos de qualquer natureza, além de quais os procedimentos logísticos e arquitetônicos serão adotados para minimizar aqueles ainda inevitáveis, tecnicamente falando; compensatórias, as quais supõem contrapartida material correspondente a impactos que não se pode evitar, a serem revertidas em obras de interesse público, como adequação de vias, construção e ou reforma de escolas, unidades de saúde, creches, entre outros (PAULINO, 2011, p. 150 e 151).

As ciclovias em Londrina vêm se expandindo lentamente e, muitas vezes, em decorrência deste instrumento, como é o exemplo dos shoppings Boulevard, Londrina Norte Shoppina e Shopping Aurora em 2013, do Hospital GBX (Palhano Medical Center), em 2016, e do Colégio Adventista, em 2017, que implantaram ciclovias na área de influência dos empreendimentos, muitas delas desconectadas da rede cicloviária existente. Em 2015, a Câmara Municipal de Londrina aprovou um projeto de lei que obriga empreendedores de condomínios e loteamentos a construírem ciclovias nas vias classificadas como Anel de Integração, Estruturais, arteriais e Coletoras, com largura mínima de vinte metros, o que vem acontecendo com os novos loteamentos.

Recentemente, a cidade de Londrina, por meio da Secretaria Nacional de Transporte e da Mobilidade Urbana, firmou um contrato com investimento de mais de 140 milhões na chamada Implantacão de Sistema de Transporte Urbano, adequando-se também ao Plano de Mobilidade Urbana e ao novo Plano Diretor Municipal em 2018.

A realidade da rede cicloviária londrinense esbarra na falta de aplicação de recursos para esse tipo de infraestrutura aliada à falta de execução do proieto existente há mais de uma década para esse modal. Por outro lado, parte da populacão também reluta em entender a importância dessa infraestrutura, que é muitas vezes considerada pouco utilizada. O resultado desta realidade mostra um número expressivo de acidentes com bicicletas nos últimos dez anos na cidade de Londrina.

\section{ACIDENTES ENVOLVENDO CICLISTAS NA CIDADE DE LONDRINA NO PERÍODO DE 2006 A 2016}

A falta de condições seguras para os transportes não motorizados, como a bicicleta, pode resultar em muitos e graves acidentes. Para entender a vulnerabilidade dos ciclistas na cidade de Londrina/PR, foram espacializados os acidentes de um período de uma década, de acordo com os dados obtidos no site do Corpo de Bombeiros de Cascavel, e o Sistema de Registro e Estatística de Ocorrências do Corpo de Bombeiros do Paraná, que é responsável pelo resgate, registro da ocorrência e disponibilização virtual dessas informações. Os dados foram tabulados a partir do $3^{\circ}$ Grupamento, que integra o município de Londrina, considerados a partir do dia 1 de janeiro de 2006 até o dia 31 de dezembro de 2016. Os tipos de ocorrência espacializados foram: acidentes entre bicicletas, acidentes envolvendo ônibus e bicicletas, acidentes envolvendo caminhões e bicicletas, acidentes envolvendo motos e bicicletas e acidentes envolvendo carros e bicicletas (Quadro 3). Com essas informações foi possível compreender qual é o principal veículo causador de acidentes com ciclistas e quais as vias mais perigosas para os ciclistas na cidade de Londrina.

Quadro 3 - Acidentes envolvendo ciclistas em Londrina no período de 2006 a 2016.

\begin{tabular}{|c|c|c|}
\hline Categoria & Acidentes (2006-2016) & Obitos \\
\hline Bicicleta x Bicicleta & 71 & 0 \\
\hline Bicicleta x Caminhão & 74 & 7 \\
\hline Bicicleta x Önibus & 76 & 2 \\
\hline Bicicleta x Moto & 730 & 11 \\
\hline Bicicleta x Carro & 1448 & $\mathbf{2 8}$ \\
\hline TOTAL & $\mathbf{2 3 9 9}$ & \\
\hline
\end{tabular}

Fonte - PARANÁ (2017) Org.: pelos autores (2018).

$\begin{array}{llllll}\text { Caminhos de Geografia } & \text { Uberlândia } & \text { v. 21, n. } 73 & \text { Mar/2020 } & \text { p. 253-268 } & \text { Página } 262\end{array}$


A seguir são listadas as 10 vias com maiores números de acidentes envolvendo ciclistas (Figura 5). A via com mais acidentes deste tipo é a Rodovia PR 445, com 104 acidentes. Em segundo se coloca a Avenida Dez de Dezembro, com 83 acidentes. Em terceiro a Avenida Saul Elkind com 76 acidentes, seguida da Avenida Tiradentes (74), Avenida Guilherme de Almeida (71), Avenida Brasília/BR 369 (64), Avenida Winston Churchil (62), Avenida "Leste-Oeste" (53), Avenida Arthur Thomas (47) e Avenida Duque de Caxias, com 45 acidentes. Das 10 vias com mais acidentes, apenas 2 contam com ciclovias e/ou ciclofaixas atualmente, embora não em todo o percurso, sendo elas a Avenida Leste Oeste, em apenas um trecho de 3275 metros, cerca de 68\% do total da via, e a Avenida Saul Elkind, com 5790 metros, perfazendo cerca de $68 \%$ do total. Nesta avenida, tal infraestrutura, que conta com recursos públicos na sua expansão, se encontra, atualmente, com a sua execução parada há mais de um ano.

Os dados confirmam que o carro é o principal veículo que se envolve em acidentes com ciclistas na cidade de Londrina/PR, acompanhado em seguida pelas motos. No entanto, os mais letais são os carros, com 11 óbitos, acompanhado pelos caminhões e ônibus, com oito e sete óbitos respectivamente.

Além de mostrar o conflito entre ciclistas e demais veículos no trânsito urbano londrinense, o número expressivo de 2400 acidentes em uma década evidenciou que a população que utiliza este veículo é maior do que se imaginava, assim como se apresenta muito vulnerável a este risco urbano.

Com base nos dados apresentados foi possível mapear as dez vias mais perigosas para o ciclista na cidade de Londrina:

Figura 5 - As 10 vias com maiores números de acidentes envolvendo ciclistas em Londrina/PR no período de 2006 a 2016.

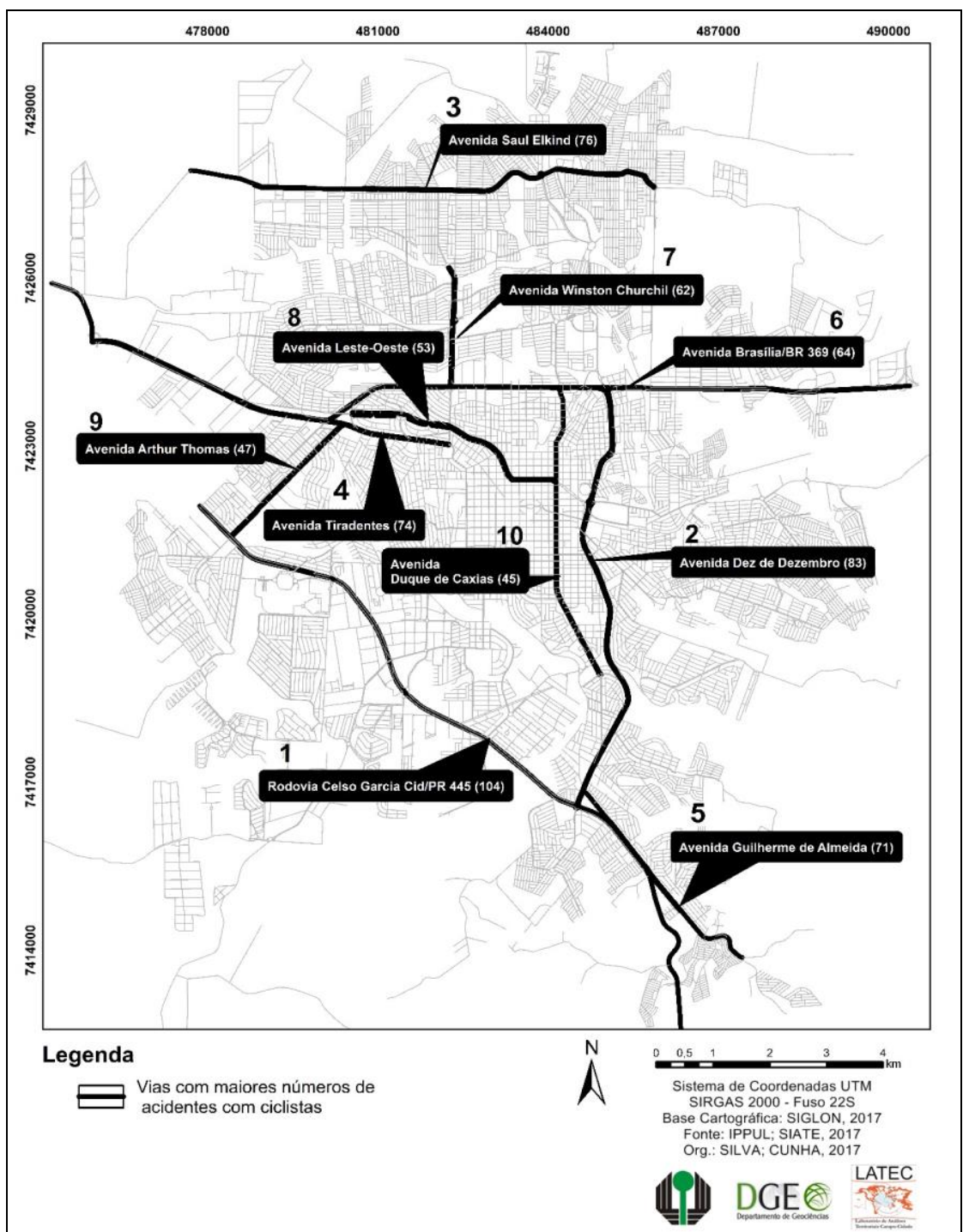

Fonte - PARANÁ (2017) Org.: Os autores (2017).

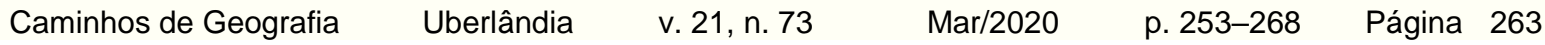


Como já mencionado, muitos dos problemas encontrados nas ciclovias e ciclofaixas estão relacionados à falta dessa infraestrutura e à manutenção dela, além da própria conscientização da população. Através de visitas in loco, tais problemas, como o desrespeito pela sinalização por parte de pedestres, ciclistas e motoristas e/ou a precária sinalização ou a falta dela, principalmente nos locais mais perigosos, como os cruzamentos, foram percebidos.

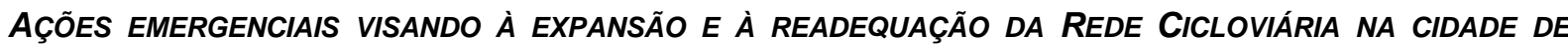 LONDRINA}

Com base na análise da Rede Cicloviária e no número de acidentes envolvendo ciclistas na cidade de Londrina, foi possível realizar uma proposta com 24 ações emergenciais, visando à expansão e à readequação da Rede Cicloviária, com o objetivo de dar maior segurança para a população que faz opção por este tipo de transporte (Figura 6 e Quadro 4).

Figura 6 - Planejamento Prioritário: Proposta emergencial de expansão e readequação da Rede Cicloviária na cidade de Londrina/PR.

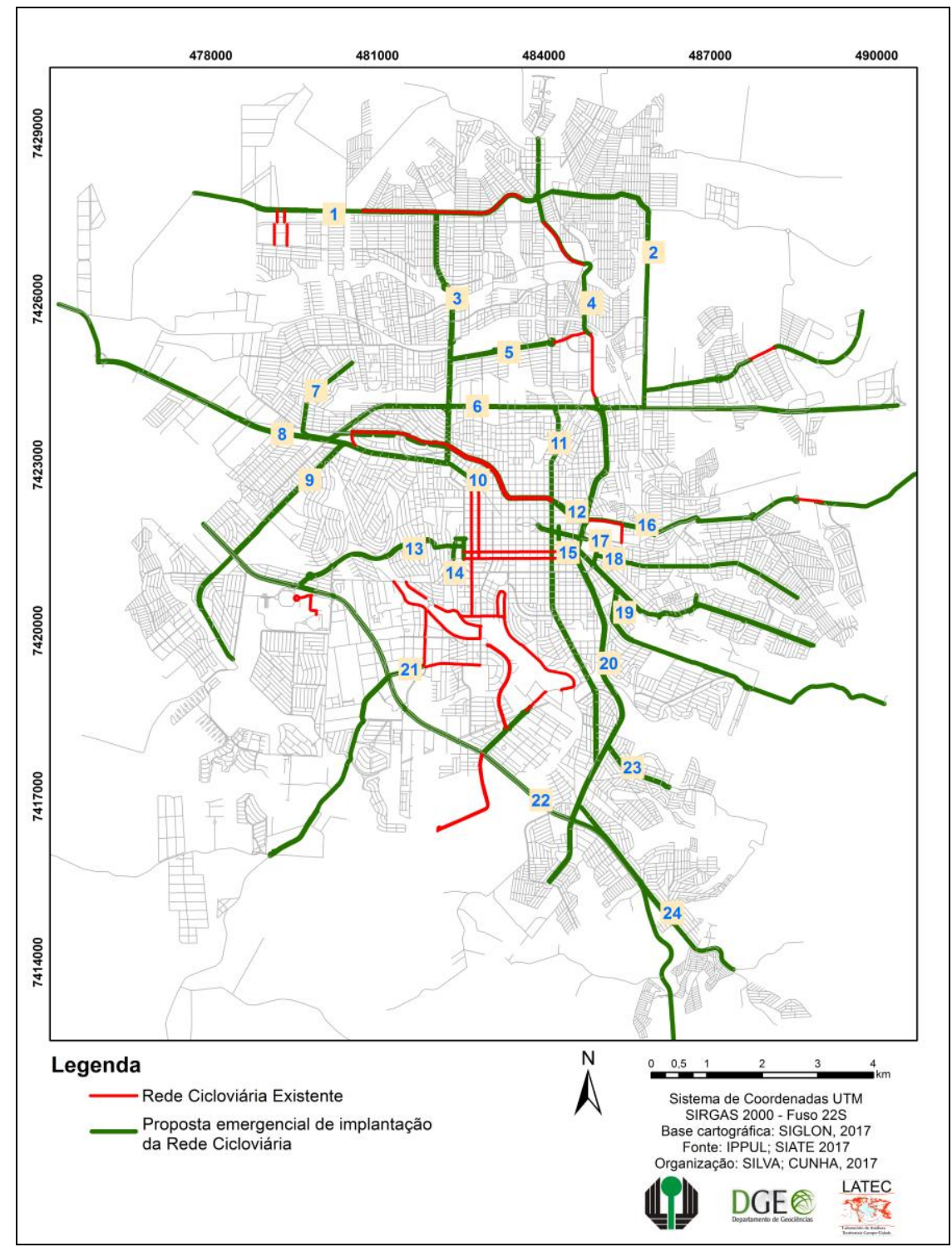

Fonte - PARANÁ (2017). Org.: Os autores (2017).

As 24 ações emergenciais buscam expandir para todas as regiões da cidade a rede cicloviária, conectando-a e priorizando as vias consideradas mais perigosas.

\begin{tabular}{|c|c|c|c|}
\hline Caminhos de Geografia & Uberlândia & v. 21, n. 73 & Mar/2020 \\
\hline
\end{tabular}


Quadro 4 - Quadro síntese da proposta emergencial para implantação e readequação da Rede Cicloviária na cidade de Londrina/PR.

\begin{tabular}{|c|c|}
\hline 1 & $\begin{array}{l}\text { Na Av. Saul Elkind, com proposta do Superbus, ligando a Av. Gabriel Arruda, à leste e Av. } \\
\text { Winston Churchill à oeste, facilitando o acesso da Zona Norte às demais regiões da cidade; }\end{array}$ \\
\hline 2 & $\begin{array}{c}\text { Na Av. Angelita Vezzozo, logo após a Av. Saul Ekind, fazendo ligação à BR } 369 \text { e Av. das } \\
\text { Maritacas, que já conta com um trecho de ciclofaixa; }\end{array}$ \\
\hline 3 & $\begin{array}{c}\text { Na Av. Winston Churchill e sua continuação na Av. Gabriel Arruda, ligando a Av. Saul Elkind } \\
\text { ao norte até a Av. Tiradentes ao sul. }\end{array}$ \\
\hline 4 & Na Rodovia Carlos João Strass, ligando a Av. Silvio de Barros à Av. Saul Elkind; \\
\hline 5 & Na Av. Henrique Mansano, ligando a Av. Wilston Churchil à Av. Silvio Barros; \\
\hline 6 & $\begin{array}{c}\text { Na BR } 369 \text { (Av. Brasília, integrando a zona leste e oeste da cidade e ligando as Avs. Rio } \\
\text { Branco e Dez de Dezembro; }\end{array}$ \\
\hline 7 & Na Rua Ruy V. Carnascialli ligando bairros da zona oeste à Av. Tiradentes; \\
\hline 8 & Na Av. Tiradentes, ligando as Avs. Arthur Thomas, Universo e Leste Oeste; \\
\hline 9 & $\begin{array}{l}\text { Na Av. Arthur Thomas e sua continuação na Av. Juvenal Pietra Roia, ligando a zona oeste até } \\
\text { a PR 445, possibilitando o acesso à Universidade Estadual de Londrina (UEL) e à ligação com } \\
\text { a Zona Sul da cidade; }\end{array}$ \\
\hline 10 & Na Rua Quintino para conectar-se à ciclofaixa da Rua Santos e dar acesso à Av. Tiradentes; \\
\hline 11 & $\begin{array}{l}\text { Na Av. Duque de Caxias, da BR } 369 \text { (Av. Brasília) passando por todo o centro da cidade e sua } \\
\text { continuação na Av. Inglaterra ligando o centro à Zona Sul com a Av. } 10 \text { de Dezembro; }\end{array}$ \\
\hline 12 & $\begin{array}{l}\text { Na Av. Leste Oeste, para completar a ligação da ciclovia que já existe, além da reparação da } \\
\text { sinalização vertical e horizontal; }\end{array}$ \\
\hline 13 & $\begin{array}{c}\mathrm{Na} \text { Av. Presidente Castelo Branco, com continuação na Rua Goiás e Av. Juscelino } \\
\text { Kubitscheck até a rua Alagoas, ligando a Universidade Estadual de Londrina ao centro da } \\
\text { cidade; }\end{array}$ \\
\hline 14 & $\begin{array}{l}\text { Na Av. Juscelino Kubitscheck ligando a rua Espírito Santo à rua Pará, com continuação na rua } \\
\text { Pará fazendo a ligação com a Rua do Escoteiro e desta com a Rua Goiás no sentido bairro; }\end{array}$ \\
\hline 15 & $\begin{array}{c}\text { Na Rua Brasil, fazendo a ligação com a rua Goiás e desta rua até a Av. Santos Dumont e sua } \\
\text { continuação na Av. Alziro Zahur e Av. Roberth Koch, ligando parte da zona leste; }\end{array}$ \\
\hline 16 & $\begin{array}{c}\text { Na Av. Teodoro Victorelli e sua continuação com a Av. das Laranjeiras e Estrada dos } \\
\text { Pioneiros ligando a Av. Dez de Dezembro a parte da zona leste; }\end{array}$ \\
\hline 17 & Na Av. Celso Garcia Cid até a rua São Pedro e desta até o final da Av. São João; \\
\hline 18 & Na Rua São Pedro ligando a Av. Celso Garcia Cid à Av. Santos Dumont; \\
\hline 19 & $\begin{array}{l}\begin{array}{l}\text { Na Av. Comandante João Ribeiro de Barros, com continuação na Av. Salgado Filho até seu } \\
\text { final; }\end{array} \\
\end{array}$ \\
\hline 20 & $\begin{array}{c}\text { Av. Dez de Dezembro e sua continuação na Av. Presidente Eurico Gaspar Dutra, com a } \\
\text { construção de ciclovia lateral; }\end{array}$ \\
\hline 21 & $\begin{array}{c}\text { Na continuação da Av. Madre Leônia Milito até a PR } 445 \text { e sua continuação na Rodovia Mário } \\
\text { Gonçalves Palhano até o Centro de Eventos; }\end{array}$ \\
\hline 22 & $\begin{array}{c}\text { PR } 445 \text { ligando as Avs. Guilherme de Almeida, Dez de Dezembro, Harry Prochet, Madre } \\
\text { Leônia Milito, Castelo Branco, Arthur Thomas e Tiradentes; }\end{array}$ \\
\hline 23 & Na Av. Europa, ligando a Av. Dez de Dezembro a parte da zona leste; \\
\hline 24 & Na Av. Guilherme de Almeida, ligando os bairros à Av. Dez de Dezembro. \\
\hline
\end{tabular}

Essas 24 ações emergenciais são necessárias para garantir maior segurança para os ciclistas, mas é fundamental que, juntamente com essa expansão e readequação infraestrutural, sejam observadas as diretrizes propostas pelo Caderno de Referência para elaboração de Plano de Mobilidade por Bicicleta nas Cidades (BRASIL, 2007), que destaca:

1) Prever, quando houver recursos, a colocação de semáforos nos acessos dos ciclistas a pontos determinados da ciclovia no canteiro central;

2) Garantir o acesso à ciclovia em todas as vias transversais:

3) Em vias com controle de acesso (semiexpressas ou assemelhadas), aproveitar as travessias nas paradas de ônibus para proporcionar o acesso dos ciclistas às ciclovias em canteiro central;

4) Adotar medidas do tipo "moderação de tráfego" (traffic calming), tais como: elevações na pista, estreitamento da via destinada aos motorizados, ou sinalização com

$\begin{array}{llllll}\text { Caminhos de Geografia } & \text { Uberlândia } & \text { v. 21, n. 73 } & \text { Mar/2020 } & \text { p. 253-268 } & \text { Página } 265\end{array}$ 
placas especiais, visando a melhorar as condições de acesso dos ciclistas e evitar maiores custos com a colocação de semáforos. Servem para vias com canteiro central que não sejam caracterizadas como vias arteriais ou coletoras;

Ter cuidado especial com a arborização do canteiro central. Deve-se avaliar se esta medida poderá implicar na diminuição do espaço da ciclovia. Também, estudar se este procedimento poderá colocar ciclistas e pedestres em zonas de sombreamento, ou com baixa visibilidade para outros usuários da via;

Projetar as principais interseções que envolvam acesso à ciclovia no canteiro central com bom nível de detalhamento, em especial, àquelas com maior demanda de ciclistas;

7) A alteração do revestimento da ciclovia é necessária, seja com a mudança de cor ou com o aumento da sua rugosidade. Com tal procedimento pretende-se condicionar os ciclistas na aproximação de cruzamentos.

8) A colocação de obstáculos laterais canaliza o fluxo de ciclistas, impedindo-os de adotarem um itinerário que não seja o mais seguro.

9) Os requisitos básicos para uma ciclovia, no tocante ao pavimento, são os seguintes: a superfície de rolamento deverá ser regular, impermeável, antiderrapante e, se possível, de aspecto agradável. Em função da convivência próxima da ciclovia com o passeio do pedestre, é desejável que a superfície da ciclovia e a do passeio sejam visualmente diferenciadas para que não haja a invasão da ciclovia pelo pedestre assim como a invasão do passeio pelo ciclista;

10) Nas ciclovias que margeiam ruas ou estradas, deve-se adotar, sempre que possível, um greide colado para evitar problemas de drenagem. A inclinação lateral da pista deve ser de $2 \%$ para favorecer um rápido escoamento das águas. Essa inclinação deverá ser sempre para o lado das vias existentes, aproveitando-se, dessa forma, o sistema de drenagem que elas possuem;

11) A solução para problemas decorrentes da inexistência de paraciclos é simples, bastando, em muitos casos, suprimir uma ou mais vagas nos estacionamentos destinados aos automóveis. É importante que essas vagas estejam localizadas o mais próximo possível do local de destino dos ciclistas;

12) Criação de ciclofaixa, quando houver disponibilidade de espaço, ou ainda, dotação de faixa da direita de sobrelargura de $1,20 \mathrm{~m}$, no máximo, para permitir a circulação de bicicletas no espaço excedente a uma faixa e criação de áreas de refúgio para a bicicleta e pedestres, na área de aproximação nos cruzamentos antes da conversão à esquerda.

A proposta emergencial de expansão e readequação da rede cicloviária de Londrina também deve ser acompanhada de um trabalho permanente de educação e conscientização no trânsito visando ao respeito mútuo entre pedestres, ciclistas e motoristas. Este trabalho é fundamental na busca de tornar o transporte por bicicletas e o trânsito como um todo mais seguro nesta cidade.

\section{CONSIDERAÇÕES FINAIS}

A utilização de bicicletas como meio de transporte é um ganho econômico, ambiental e social. O ganho econômico está na indústria, comércio e prestação de serviços voltados para a bicicleta, gerando trabalho e renda. O ganho ambiental se configura na redução da emissão de gases poluentes, reduzindo, consequentemente, gastos com o sistema de saúde pública a longo prazo. O lado social da bicicleta se dá pelo seu baixo custo tanto de aquisição quanto de manutenção, proporcionando a inclusão do indivíduo no sistema de transporte da cidade, permitindo-lhe maior flexibilidade e alcance nos deslocamentos, principalmente quando integrada com os demais modais de transporte.

A análise dos acidentes cicloviários ocorridos durante os anos de 2006 a 2016 e as ciclovias existentes na cidade de Londrina evidencia um descompasso entre os projetos executados e os problemas existentes. Das dez vias com maior número de acidentes apenas duas contam com ciclovias ou ciclofaixas, ainda que em estado precário. Com base nesta análise, o presente trabalho apresentou uma proposta emergencial objetivando a implantação ou readequação de ciclovias e ciclofaixas com 24 ações que visam facilitar e dar maior segurança ao tráfego por bicicletas. Tal proposta pode colaborar com os órgãos públicos na elaboração de um Plano de Mobilidade para o Município que inclua um projeto cicloviário. A Rede Cicloviária existente apresenta deficiências na qualidade e na pouca conexão do traçado existente, apresenta também larguras incompatíveis com

\begin{tabular}{llllll}
\hline Caminhos de Geografia & Uberlândia & v. 21, n. 73 & Mar/2020 & p. 253-268 & Página 266
\end{tabular}


as normas e com as demandas efetivas, além de baixa qualidade de execução e manutenção dessa infraestrutura. Uma sugestão é a manutenção da cobrança dos órgãos públicos relacionada às medidas mitigatórias pelos novos empreendimentos, previstas pelo Estudo de Impacto de Vizinhança, responsabilizando-os pelo instrumento de forma a garantir a segurança e o bem-estar do ciclista. Apesar de não ser obrigatório, é válido também sinalizar as vias com a cor vermelha, deixando de forma clara que o espaço é do ciclista e deve ser respeitado.

Apesar das ciclovias servirem para mobilidade, isso ainda não é expressivo em Londrina. As condições atuais favorecem principalmente o lazer de poucos apesar da pesquisa realizada pelo IPPUL trazer que $60 \%$ utilizam a bicicleta para trabalho e estudo. É expressiva a presença da infraestrutura cicloviária na área central e centro-sul da cidade, principalmente nas áreas mais nobres, trazendo à tona a dualidade entre o ciclista que realmente precisa da bicicleta para se locomover e aquele que á utiliza para lazer. Ora, é preciso que a rede contemple as áreas residenciais, de comércio e serviços nas principais zonas das cidades e às integre visando sempre a segurança e o melhor traçado, incluindo as condições topográficas do sítio urbano formando tramos cicloviários integrados. Não basta apenas construir uma rede cicloviária, é necessário também promove-la. Muitos cidadãos ainda desconhecem a importância deste meio de transporte e ainda refutam a criação de ciclovias e ciclofaixas. Campanhas para pedalar até o trabalho ou à escola devem ser articuladas, quebrando o argumento de que fatores como clima ou topografia impedem o uso da bicicleta. Também é preciso integrar a bicicleta ao transporte público com bicicletários e paraciclos em pontos de conexões determinados, para que se tenha a mobilidade necessária em locais de difícil acesso por bicicletas.

\section{AGRADECIMENTOS}

À Fundação Araucária (FA) e ao Conselho Nacional de Desenvolvimento Científico e Tecnológico (CNPq) pela concessão de bolsa para realização da pesquisa e ao Instituto de Pesquisa e Planejamento Urbano de Londrina (IPPUL) pelas informações concedidas.

\section{REFERÊNCIAS}

BRASIL. Decreto-lei $\mathbf{n}^{\circ}$ 9.503, de 23 de setembro de 1997. Institui o Código de Trânsito Brasileiro. Diário Oficial da República Federativa do Brasil, Brasília, 23 set. 1997.

Decreto-lei $n^{\circ}$ 10.257. Estatuto da cidade, de 10 de julho de 2001. Regulamenta os artigos. 182 e 183 da Constituição Federal, estabelece diretrizes gerais da política urbana e dá outras providências. Diário Oficial da República Federativa do Brasil, Brasília, 11 jul. 2001.

. Ministério dos Transportes. Empresa Brasileira de Planejamento de Transportes GEIPOT. Manual de planejamento cicloviário. $3^{\mathrm{a}}$ ed rev. e amp. Brasília: GEIPOT, 2001b. Disponível

em: <http://projects.mcrit.com/tiete/attachments/article/291/Manual\%20de\%20planejamento\%20ciclovi\%C 3\%A1rio\%20-\%20GEIPOT\%20-\%202001.pdf> Acesso em 02 dez 2017.

Ministério das Cidades. Programa Brasileiro de Mobilidade por Bicicleta - Bicicleta Brasil. Caderno de referência para elaboração de Plano de Mobilidade por Bicicleta nas Cidades. Brasília: Secretaria Nacional de Transporte e da Mobilidade Urbana, 2007. Disponível em: <http://www.cidades.gov.br/images/stories/ArquivosSEMOB/Biblioteca/LivroBicicletaBrasil.pdf> Acesso em 02 dez 2017.

Decreto-lei $\mathrm{n}^{\circ}$ 12.587, de 3 de janeiro de 2012. Institui as diretrizes da Política Nacional de Mobilidade Urbana. Diário Oficial da República Federativa do Brasil, Brasília, 3 jan 2012.

Ministério da Saúde. Datasus - Departamento de Informática do SUS. 2018a. Disponível em: <http://datasus.saude.gov.br/>. Acesso em 03 mar 2018.

Ministério das Cidades. Departamento Nacional de Trânsito - Frota. 2018b. Disponível em: <https://www.denatran.gov.br/frota.htm> Acesso em 03 mar 2018.

CUNHA, F. C. A. Regiões metropolitanas paranaenses: descompasso entre espacialidade e institucionalidade e a necessidade de uma reforma institucional. Revista Paranaense de Desenvolvimento, volume 35, n. 127, p. 181-203, jul./dez., 2014.

$\begin{array}{llllll}\text { Caminhos de Geografia } & \text { Uberlândia } & \text { v. 21, n. 73 } & \text { Mar/2020 } & \text { p. 253-268 } & \text { Página } 267\end{array}$


DUTRA, C. B. Pesquisa sobre transporte não-motorizado realizado por bicicleta na cidade de Londrina. DETRANSITO, Paraná, ano V, no 47, p. 24- 31, nov/dez, 2007.

GEIPOT - GRUPO EXECUTIVO DE INTEGRAÇÃO DA POLÍTICA DE TRANSPORTES. Inventariança da Extinta Empresa Brasileira de Planejamento de Transportes - GEIPOT: A Empresa, [200-]. Disponível em: <http://www.geipot.gov.br/> Acesso em 10 nov 2017.

IPPUL - INSTITUTO DE PESQUISA E PLANEJAMENTO URBANO DE LONDRINA. Rede Cicloviária de Londrina 2013. Disponível em: <http://ippul.londrina.pr.gov.br/index.php/redecicloviaria-de-londrina.html> Acesso em 29 nov 2017.

KRAFT, W. H. Planning design and implementation of bicycle and pedestrian facilities. New Orleans, Louisiana, 1975.

PARANÁ, Corpo de Bombeiros - Sistema Integrado de Atendimento ao Trauma e Emergência. Sistema de Registro e Estatística de Ocorrências do Corpo de Bombeiros. Disponível em: <http://www.bombeiroscascavel.com.br/registroccb/imprensa.php> Acesso em 8 out 2017.

PAULINO, E. T. Estudo de impacto de vizinhança: alguns apontamentos a partir do caso de LondrinaPr. Caderno Prudentino de Geografia, Presidente Prudente, n. 33, v. 2, p. 146-169, ago/dez. 2011. SOUZA, G. B. A mobilidade por bicicleta na Política Nacional de Mobilidade Urbana. Ensaio Crítico - Turma 11, ANTP, 2013, p. 1-4 Disponível em: <http://www.antp.org.br/_5dotSystem/userFiles/EnsaiosCriticos/Turma11/Gabriela\%20Binatti.pdf> Acesso em 03 dez 2017.

Recebido em: 09/06/2019

Aceito para publicação em: 13/12/2019 